\title{
Temptation of the "Powerful": The politics of electoral reform in Central Europe in post-transitional period
}

\author{
Jakub Charvát ${ }^{1}$
}

\begin{abstract}
The paper explores and analyses processes of electoral reforms in selected Central European countries (the Czech Republic, Hungary, Slovakia, and Slovenia) in posttransitional period. The qualitative analysis focuses "only" on the enacted changes in electoral systems and its purpose is not to evaluate the impact and political consequences of individual changes but rather to concentrate, through a theoretically-informed detailed contextual analysis, on the electoral reform process itself. It is therefore concerned with contextual factors affecting, underlying, initiating and/or controlling these changes. The paper identifies political elites as the main actors of electoral reform processes in selected countries, and it tries to explain both motivations of political elites for changing status quo electoral systems and other circumstances of electoral reform processes in Central Europe as well. The analysis also suggests that processes of electoral reform in post-transitional period in Central Europe are characterized by a tendency to less proportional electoral system designs, with the only exception of the Slovak electoral reform of 1999 (due to specific political constellation), while it did not discover any clear tendency regarding personalization of electoral systems.
\end{abstract}

KEY WORDS: electoral systems, politics of electoral reform, Central Europe, proportionality, personalization, post-transitional period.

\section{INTRODUCTION}

It is generally believed among political scientists that institutions "matter", and elections lie at the very heart of modern democracy. As Giovanni Sartori (1968) notes electoral systems are "the most specific manipulative instrument of politics" which means, inter alia, that variation in electoral institutions affects how other institutions and actors of political process behave. It also determines the identity of those who will govern, and to some extent how governing power is exercised. Or in other words, electoral systems represent one of the fundamental pillars of modern (representative) democracy and they affect functioning of other political institutions. David Farrell (2001, p. 2) therefore called electoral systems wheels maintaining proper functioning of democracy.

\footnotetext{
${ }^{1}$ Jakub Charvát, Ph.D., Department of Political Studies and Humanities, Metropolitan University Prague, Dubečská 900/10, 10031 Prague 10, Czech Republic. Email: jakub.charvat@mup.cz
} 
Given the importance of electoral systems and their political consequences, especially on the number of parties and political composition of parliaments and governments, it is essential that we understand where these rules come from and why and how they are changed. However, whilst some positive shift has been achieved recently, the issue of the origin of electoral systems remains inadequately dealt with in literature. This is a continuously forming research perspective within the current research in comparative politics, which is slowly becoming one of the leading themes of the election analysis, since it comes to the forefront of interest of an increasing number of authors (and publications). At the same time, it is a research area, which only little attention has been paid to so far in both the Czech and Slovak Republics. Although there are several case studies on partial changes to electoral systems and the development of electoral legislation in a selected country, however, these are often limited to a "mere" description of the changes, but without any ambition to explain the factors and causes of these changes. Alternatively, these changes are examined with regard to effects of the changed (new) electoral systems (see Chytilek and Šedo, 2007).

But without understanding the origin of electoral systems and the reasons for their introduction, it is not possible to fully understand their effects and consequences. Therefore, the aim of the text is to partly fill in the indicated "gap", in the form of a comparative analysis of the post-transitional politics of electoral reform in Central Europe, defined for the purposes of this study as the Czech Republic, Hungary, Slovak Republic, and Slovenia.

\section{ELECTORAL STUDIES AND THE POLITICS OF ELECTORAL REFORM}

Electoral institutions and electoral systems are a subject of relatively large numbers of political science literature. The study of electoral systems and their mechanisms is actually among the most important topics of comparative political science analyses. Understanding the consequences of electoral systems is a very important factor for studying the processes of governance, the nature of government and coalition formation processes in the pre-election and postelection period, format and size of the party system and the overall stability of regimes. Not surprisingly, the traditional and still dominant approach to studying electoral systems focuses on examining effects of different electoral rules. Roots of this research tradition can be found in Maurice Duverger (1951), followed later by Douglas W. Rae (1967/1971), who expanded the systematic study of electoral systems with quantitative data analysis methods. Electoral systems are seen as independent variables and the main goal of this approach is to define and categorize different types of electoral systems and to analyse their effects and consequences for both the party and political system. Most of the studies and 
analyses based on this research have mostly an empirical perspective and focus mainly on quantitative methods of data analysis.

For a relatively long time, theorists of electoral systems proceeded from the conviction that electoral systems are stable institutions since the time of their establishment, mainly due to historical and contextual factors (Leyenaar and Hazan, 2011, p. 437). Fundamental changes in electoral rules only occur in exceptional historical situations (Nohlen, 1984, p. 217), typically when a political system is undergoing a constitutional crisis, or if it is on the verge of collapse. Moreover, despite many shortcomings most existing electoral systems are perceived as meeting the purpose of their existence (creating a stable institutional framework) better than new (and unknown) systems could, even if the new system was inherently advantageous (Taagepera and Shugart, 1989, pp. 218, 236).

In this perspective, preservation of known shortcomings of the existing system is a better solution than a change, because all possible consequences cannot be known in advance. This is further supported by the specific character of elections as a redistributive institution (Tsebelis, 1990), which are a zero-sum game; the total amount to win in the game is final and immutable, so it concerns a possible improvement of the status of one player at the expense of other players, and it is in this context where we can perceive any change as an ambition to improve their position at the expense of others. Another source of stability of electoral systems is that those, who are able to carry out electoral reforms, are also those, who are successful under the current conditions.

Only in the last twenty years there has been a fairly rapid expansion in studies of electoral reforms (Leyenaar and Hazan, 2011; Pilet and Bol, 2011, p. 569), while the incentive to intensify studies of electoral reforms have become electoral reforms in consolidated systems in the first half of 1990s (in New Zealand, Japan, Italy and Israel), as well as discussions about the possibility of electoral reforms in the United Kingdom in 1990s. Over time, the authors have began to increasingly focus on the issues of electoral reform in democratizing countries of Central and Eastern Europe (e.g. Juberías, 1995; Ishiyama, 1997; Birch et al., 2002; Birch, 2003; Juberías, 2004; Chytilek and Šedo, 2007; Šedo, 2007; Charvát, 2013; Charvát et al., 2015) as well as in other new democracies.

A new research perspective in electoral studies, the politics of electoral reform (Renwick, 2010), focuses on description and explanation of the processes of adoption of new electoral systems, partly to explain the causes of their changes. In this perspective, electoral systems are best viewed as dependent variables. Josep Colomer (2004, pp. 3-4; 2005) therefore calls the initial logic of this approach "Duverger's laws upside down", because electoral systems usually crystallize, consolidate or even strengthen the existing political party configuration, rather than creating new party systems or new political results on 
their own. This, however, is not to deny the validity of Duverger's hypotheses (see Duverger, 1951). The politics of electoral reform, however, aims to test the relationship between the party and electoral systems in the broader analytical and contextual framework, including also the process of selecting and changing electoral institutions by already existing political actors, especially parties.

The politics of electoral reform influenced even hitherto dominating methodology of electoral studies; qualitative analyses appear more beneficial for its needs, while quantitative studies remain an exception. The politics of electoral reform is a complex process, which is determined and shaped by a range of factors (historical, cultural, institutional, contextual or personnel) and which cannot be understood without a previous analysis of the mechanisms through which these factors interact and subsequently form concrete results (Renwick, 2010, pp. 84-85). Analyses of the processes of electoral reforms are therefore not largely affected by statistical data, focusing instead on a detailed comparative process tracing and primarily consist of a detailed examination of a small number of cases.

\section{THE POLITICS OF ELECTORAL REFORM IN CENTRAL EUROPE: A FRAMEWORK FOR ANALYSIS}

\subsection{Electoral reform: a definition}

Although one can often come across the terms such as "reform" and/or "electoral reform", respectively "electoral engineering" in political science literature, there is no consensus among the authors on what exactly these terms mean. For the purposes of this study "electoral reform" means the process of selecting or changing an electoral system, rather than any change in the electoral law. Building on Farrell (2001, pp. 3-4), the analysis is based on a distinction between the terms "electoral law" and "electoral system". The electoral law is a wide range of rules and laws framing the entire process and organization of elections (the electoral process), from the manner of announcing elections and their requirements, through establishment of rules of individual phases of the nomination of candidates, campaigns, voting and counting the votes to the way of announcing results and the possibility of filing a complaint about the process of elections or financial contributions to candidates of political parties. On the contrary, the term "electoral system" refers to "only" one set of rules from the complex electoral legislation. Electoral systems are sets of rules, through which representative seats are filled according to the number of votes from voters during the process of electing public authorities (including the questions, how to vote, how ballots or constituencies look like, how the votes are counted, how a mandate is filled by deputies, etc.). 
Richard Katz (2005, pp. 58-59) distinguishes between "major" and "minor" electoral reforms. If the electoral formula is replaced (such as the plurality electoral system replaced by the proportional one, and vice versa), Katz refers to this process as a "major" electoral reform. If there is "only" a change in some parameters of the electoral system (such as district magnitude, electoral threshold, mathematical formula, etc.), while maintaining the electoral formula, Katz talks about a "minor" electoral reform. While "major" electoral reforms are quite a rare and exceptional phenomenon in consolidated democracies (Katz, 1980, p. 123; Nohlen, 1984, p. 218; Cox, 1997, p. 18; Katz, 2005, p. 58; Renwick, 2010; Bowler and Donovan, 2013, pp. 6-8), although they are considerably more likely to occur in new democracies (Colomer, 2004; Katz, 2005, p. 59; Renwick, 2010, p. 4; Bowler and Donovan, 2013, p. 8), "minor" electoral reforms occur relatively frequently in both old democracies and new ones (Renwick, 2011).

But as pointed by Roman Chytilek and Jakub Šedo (2007, p. 33), such a distinction is insufficient and its heuristic capacity is only limited. Even within the same electoral system, we can identify ("minor") electoral reforms, the effects of which are comparable to replacing the electoral formula (a "major" reform); an example could be the Czech electoral reform process of 2000, which consisted of only minor changes of the electoral system, but had a significant disproportional (majority creating) aspects. For the purposes of this study, therefore, an electoral reform means any significant change to the existing electoral system; among others, because "major" electoral reforms occurred in the examined countries only when choosing rules for the founding elections. In this study are therefore examined cases of electoral reforms, which meet criteria set by Arend Lijphart (1994, p. 13), p. any change to the electoral formula, at least twenty per cent change of the electoral threshold, district magnitude or assembly magnitude.

The study seeks to understand how the electoral systems in selected Central European countries (the Czech Republic, Hungary, Slovakia, and Slovenia) were changed. Electoral systems are hence seen as a dependent variable here. The study follows the process of changes of rules of elections to the national parliaments or to their first chambers (if it is bicameral, as it is the case in the Czech Republic). It focuses mainly (but not only) on the enacted changes in electoral systems in post-transitional period (for more details see Table 1), and although it mentions unsuccessful or failed attempts, it does not give them much attention.

\subsection{Two waves of the politics of electoral reform in Central Europe}

An analysis of the processes of electoral reform in post-communist Central European countries in the last twenty-five years confirmed the need to 
distinguish at least two waves which - in terms of assessing the electoral-reform process - significantly differ. While the first (transitional) phase of the politics of electoral reform in Central Europe corresponds to the period of transition of the surveyed political systems to democracy and exhibits a number of related specifics, in the later (post-transitional) period, it is already possible to watch many of the trends typical for electoral reforms in consolidated democracies. In other aspects, however, the politics of electoral reform in new democracies in Central Europe remains in the post-transitional period largely specific compared to established democracies, and Central European cases of electoral reform do not match expectations from the literature analyzing changes in electoral systems in established democracies. It must however be emphasized that it would be insufficient to relate the first period only to the processes of searching for rules for the founding elections, and there could be a search for a new electoral legislation, while such electoral-reform processes showed similar properties and characteristics as the period preceding the founding elections (as it was the case in Czechoslovakia in 1992, for example).

The second phase of the politics of electoral reform in Central Europe can be examined since the moment, when main political parties are formed and stabilized, and when at least some basic patterns of interaction within individual party systems are more or less established. While the first phase of the politics of electoral reform was strongly affected by contemporary circumstances, especially by the need to create conditions for competitive elections in the situation of uncertainty and lack of shared information, the second phase of changes in electoral systems already have mostly purposeful and deliberate character, mainly because of the declining general uncertainty and as political actors are already better aware of how to assert their interests. In the posttransitional period, inclusiveness and proportionality of electoral systems and the related higher level of parliamentary fragmentation was already perceived less positively than in the first phase, and these phenomena were increasingly more criticized (for more details, see Charvát et al., 2015).

Table 1: Examined processes of electoral reform

\begin{tabular}{llc}
\hline Year & Country & Law no. \\
\hline 1998 & Slovakia & $187 / 1998$ \\
\hline 1999 & Slovakia & $223 / 1999$ \\
\hline 2000 & Slovenia & $46 / 00$ \\
\hline 2000 & Czech Republic & $204 / 2000$ \\
\hline 2002 & Czech Republic & $37 / 2002$ \\
\hline 2011 & Hungary & $2011 /$ CCIII \\
\hline
\end{tabular}

Source: Charvát et al. 2015, p. 19, Table 1.1. 


\subsection{Studying changes in electoral systems in Central Europe: an analytical framework}

Building on Alan Renwick (2011), the purposes of the research are twofold. First, the study focuses on the "who" and the "why" questions, where the "who" is considered to be the identity of the actors involved in the reform process and the "why" means motivations of this actors for introducing any changes in the existing electoral system (cf. Renwick, 2011, p. 457). In this part, its purpose is therefore not to evaluate the impact of individual changes but rather to concentrate, through a theoretically-informed detailed contextual analysis, on the electoral reform process itself. The concern of the research is hence very much with the process rather than the substance of change. It is concerned with contextual factors affecting, underlying, initiating and/or controlling these changes, and it seeks to identify the main actors, their motivations and other circumstances of each electoral reform process. Processes of electoral reforms in fact did not take place in a vacuum. Each of electoral reforms has its roots in a specific power-political constellation and reflects the political reality of its time. Without their analysis, it is not possible to understand the different electoralreform processes and their results (cf. Renwick, 2010, pp. 84-85). This is why it surveys and analyses circumstances, in which the issue of electoral reform became part of the political agenda in the examined countries.

Answers on the above mentioned questions, "who" and "why", enable Renwick (2011) to suggest a typology of processes of electoral reform. When focusing on actors playing significant decision-making roles in the electoralreform processes, Alan Renwick distinguishes five ideal types of reform processes. These are placed on a continuum from reforms dominated by citizens ("mass imposition"), which is rather a theoretical case because, as Alan Renwick (2011, p. 458) points out, "it is difficult to keep politicians out an issue that so directly affects their personal interests", to processes dominated by politicians ("elite imposition"), which is the most common path of electoral reform. In the middle of this continuum are cases where politicians and citizens somehow share influence over the final decision ("elite-mass interaction"). This type can take three forms according to the extent to which are citizens and politicians involved in the reform process. In cases of "active mass impetus" process, "mass action pressurises politicians to accept change". In cases of "passive mass impetus", politicians seek to respond to public opinion by proposing a change in line with voters' desire. Reforms by "mass constraint" are characterized as changes intended by politicians "constrained from doing so by fear of upsetting public opinion" and possible subsequent voter backlash (Renwick, 2011, pp. 457-458).

The elite-imposed reform processes may, however, vary and it is beneficial to further distinguish four ideal subtypes of this path to electoral reform through the two above mentioned questions. In the case of elite imposition type of 
electoral reform process, the question "who" asks about the degree of inclusiveness of political elite in the reform process ("the extent of agreement among politicians for changing the system"). The question "why" seeks to explain what are the motivations of the political elite to change the existing political system, i.e. whether politicians seek to bring a general benefits (electoral systems are seen as efficient institutions by politicians), or to advantage themselves (politicians see electoral institutions in redistributive terms; for more details on the distinction between efficient and redistributive institutions see Tsebelis, 1990). Individual ideal types within this fourfold typology of elite-imposed processes of electoral reform are as follows. "Elite majority imposition" is used to describe cases where politicians in the majority (i.e. low degree of inclusiveness) impose over opposition a change in order to benefit themselves (redistributive conception of electoral systems). This type of elite-imposed electoral reform process best matches the micro-mega rule of Josep Colomer, under which big parties favour small electoral institutions, and vice versa (see Colomer, 2004, p. 3, 2005, p. 2). Under the "elite bargain" type, the electoral system is changed "through wide agreement among politicians, but those politicians think overwhelmingly of their own interests", while in cases of "elite settlement", politicians cooperate (high degree of inclusiveness of political elite) "to pursue their understanding of the general good" (electoral systems as efficient institutions). Finally, reforms by "elite majority concession" involve processes where "politicians in the majority introduce reforms in order to promote general values but have to impose it over minority opposition" (for more details see Renwick, 2011, pp. 458-460).

Although the contextual environment provides the basic framework for an explanation of the theoretical choice of electoral systems (Lundell, 2010, pp. 12), the study focuses, despite the research has not been primarily concerned with the rational choice perspective, both on the analysis of the political context, within which actors made their decisions regarding electoral systems, and on the performance of individual strategies of relevant actors in the process of electoral reforms, including access of political elites to electoral institutions and efforts to outline factors that led the actors to choose their strategies. This is mainly due to the fact it is typical for all cases in the analysed countries that electoral reforms were implemented "from above" as elite imposition processes, and therefore that all the examined electoral-reform processes were dominated by political elites, while ordinary citizens did not have space to actively participate in the process. Similarly, influence of experts on electoral systems, political institutions or constitutional law was relatively small.

Second, the paper analyzes political consequences of examined changes in the electoral systems, both proportionality of new electoral design as compared to the previous one at the level of inter-party dimension, and personalization at 
the level of intra-party dimension of electoral systems. Although there is a number of methods how to measure proportionality of electoral systems (see, e.g., Monroe, 1994; Taagepera and Grofman, 2003; Borisyuk, Rallings and Thrasher, 2004; Chytilek et al., 2009, pp. 79-89; Charvát, 2010; Cabada, Charvát and Stulík, 2015, pp. 200-203), the political consequences of different electoral designs take effect in the long-term perspective, which seems to be not entirely suitable for the purpose of this study. Hence, building on the conventional knowledge about the effects of various parameters of electoral systems on proportionality and personalization, the research strategy here is to compare the stimuli of the old and new electoral systems for promoting higher (dis-)proportionality and personalization. As a consequence, the main findings of this analysis are whether the new electoral design includes incentives for being more (or less) proportional and personalized than the old one, or whether there is no significant change in this respect.

\section{ELECTORAL REFORM AS A TEMPTATION OF THE POWERFUL: POST-TRANSITIONAL CHANGES IN ELECTORAL SYSTEMS IN CENTRAL EUROPE}

Potential implementation of electoral reforms in the post-transitional period was conditioned by the appropriate political constellation, where at least one of the relevant political actors must be convinced that the proposed electoral reform will bring some advantages over the status quo (most often, of course, this benefit has a form of greater parliamentary representation than in the existing electoral system), and at the same time initiators of the electoral reform process must be able to enforce this change. Specifically defined (qualified) majority approvals are required for adoption of electoral laws and in many cases they are traditionally larger than in case of standard legislative processes (e.g., an majority in both chambers in the Parliament of the Czech Republic in case of the "minor" electoral reform, and a three-fifths majority in both chambers in case of the "major" electoral reform, or a two-thirds majority in the National Assembly in Hungary, see below).

It is generally true that until such an approval majority exists, an electoral reform does not take place. At the same time it turns out in the examined cases that once it is possible to establish such approval majority, political parties pursuing the strategy of maximizing of their own profits do not hesitate to implement the electoral reform - whether it was the case of the "Mečiar's" electoral reform in the Slovak Republic in 1998, the "opposition-agreement" electoral reform in the Czech Republic in 2000, or the recent "Orbán's" electoral reform in Hungary in 2011. 
The very Hungarian case, where the second electoral reform took place "only" in 2011, is thus an example, which shows that until there is a sufficiently strong majority, the electoral reform does not take place, but once this majority exists, members of this majority will attempt to improve their position by changing the electoral system. Although there are many other explanations of the stability of the Hungarian electoral system since 1989, especially that it effectively fulfilled its primary mission (to establish strong and stable governments), the fact remains that at the first possible opportunity the existing electoral system was changed. A qualified two-thirds majority is required to adopt electoral laws in Hungary, while until then only two Hungarian governments in the post-communist era relied on such a strong majority in the National Assembly (Országgyülés) - coalition government led by Prime Minister Gyula Horn (1994 to 1998) and the second Viktor Orbán's government (2010 to 2014). But the Horn's coalition government did not form any legislative coalition for the purpose of electoral reform, because the two parties of the government coalition, the Hungarian Socialist Party and the Union of Free Democrats, would be hardly able to find a consensus on this issue. And so the first case, when it was possible to implement an electoral reform in Hungary, was the second Orbán's government from 2010. Although the electoral system fulfilled its purpose in 2010 and enabled formation of a strong government (holding the two-thirds majority in the National Assembly), this government then changed the electoral system in the following year.

Central European processes of electoral reforms thus have mainly a form of being enforced by a government majority in the second phase, while the character of introduced changes favours large political parties. In the Czech case in 2000 and in the Hungarian case in 2011, this goal was to be achieved by introduction of restrictive electoral systems (with a strong disproportional effect) in accordance with the logic of the micro-mega rule (Colomer, 2004, p. 3; Colomer, 2005, p. 2). However, we can see the opposite logic with the same goal in the case of Slovak electoral reform in 1998, where the ruling party, the Movement for Democratic Slovakia, tried to gain an advantage in their favour by introducing a nationwide electoral district instead of four regional districts in order to concentrate their electoral support around a single leader, the then Prime Minister Vladimír Mečiar (1994 to 1998). This change in electoral system was then amended by introducing an additive electoral threshold for electoral coalitions, furthermore reinforced by the principle of intra-coalition clause, which basically made it impossible for smaller parties to set up electoral alliances, in this case an electoral coalition against the (Mečiar's) Movement for Democratic Slovakia.

Yet even in the second phase of Central European politics of electoral reform, it was possible to see two electoral-reform processes among the examined cases 
involving a wider range of political actors than just a majority government, elite settlement type of electoral-reform process in case of Slovenia in 2000, and elite bargain type in case of the Czech Republic in 2002 (see Table 2). ${ }^{2}$ However, it must be emphasized that both the Slovenian electoral-reform process of 2000 and the Czech one of 2002 are specific cases, where an outside interference of external actors played its role.

In the case of the Slovenian electoral reform of 2000 this agreement responded to the problematic interpretation of the Constitutional Court, which the political elites refused to accept, because it brought a risk of a major schism in the society and its mobilization and radicalization. The resulting agreement then decreased both the level of polarization between the political actors, even if only partially, and the risk of its occurrence in the society.

The Czech electoral reform of 2002 was influenced by two external factors: first, the intervention of the Constitutional Court, which cancelled most of the provisions of the revised election law in January 2001, which compelled the political elites to adopt a new electoral law; second, changing of the constellation of power, when the autumn 2000 Senate elections deprived the "oppositionagreement" parties, the Czech Social Democratic Party and the Civic Democratic Party, ${ }^{3}$ of their majority representation in the Senate in favour of the parties opposing the electoral reform of 2000 . As it is required in case of the legislative process of election laws in the Czech Republic that identical wording of the law is approved by an absolute majority of members in both chambers of the Parliament of the Czech Republic, it was therefore newly necessary - with regard to the parliamentary composition - to include more political actors into the electoral-reform process. Although Alan Renwick (2011, p. 466, Tab. 1) calls this electoral reform process in 2002 an "elite majority imposition with a judicial

\footnotetext{
${ }^{2}$ However, Alan Renwick (2011) identifies the Czech electoral reform process of 2002 as an "elite majority imposition with judicial constraint" (see below) and the Slovenian process of 2000 as an "elite-mass interaction (active mass impetus) and judicial engagement".

3 The so-called "Opposition agreement" (officially "The agreement to create a stable political environment in the Czech Republic"), was signed by leaders of two Czech major competing parties, the Czech Social Democratic party and the right-wing Civic Democratic Party, in July 1998. The agreement enabled the Czech Social Democratic Party to form a single-party minority cabinet led by Prime Minister Miloš Zeman with the Civic Democratic Party law-makers support. In addition, the minority Social Democratic cabinet received a guarantee that deputies of the "opposition" Civic Democratic Party would neither initiate nor support a non-confidence vote. In return, the Civic Democratic Party received several politically relevant posts, including the chairmanships in both chambers of the Parliament of the Czech Republic, as well as a number of posts in state agencies and state-run and semi-state-run enterprises on an informal base. Moreover, the two parties mutually agreed to propose within one year of the agreement's signing changes to the Constitution and electoral law to strengthen its majority creating elements and hence favour major parties at the expense of the smaller ones (for more details see, e.g., Roberts, 2003, Kopeček, 2015).
} 
constraint", such a term would rather correspond to the process of the "opposition-agreement" electoral reform of 2000 (elite majority imposition), and the subsequent finding of the Constitutional court judgment in 2001 (judicial constraint). Nevertheless, the subsequent electoral reform process leading to adoption of the electoral law of 2002 corresponds to the type of bargain among political elites. Had it not been for the opposition-agreement electoral reform and/or the subsequent intervention by the Constitutional Court, the electoral reform of 2002 would not have taken place, or at least it would not have had this form and such inclusive engagement of political actors in the electoral-reform process.

Crucial players of the second phase of the politics of electoral reform in Central Europe are thus political elites, while other actors do not play any important role in the process of decision-making, whether it concerns judges, whose role is - in accordance with the evaluation of Alan Renwick (2011) limited to a negative decision and judges thus do not become constructive actors in electoral reform processes, or whether it concerns ordinary citizens, who are in many cases an ordinary part of electoral-reform processes in old democracies, or external actors. Similarly, the entry of the examined countries into the European Union did not significantly affect their electoral systems for the national parliaments.

As regard the number of electoral reforms in the post-transitional period in the examined Central European countries, the assumptions that electoral institutions in post-communist countries of Central Europe become stable after the second competitive elections or that only minor changes in the electoral legislation occur after the second elections (Rose and Munro, 2003) can be also refuted. On the one hand, it is true that after second elections there has been no "major" electoral reform within the meaning of the terminology according to Richard Katz (2005), however in several cases political consequences of the asserted electoral reforms are (as was the case of Hungary in 2011) or could be (as it was the case of the Czech Republic of 2000) essential and their overall impact is at least comparable to changes in the basic electoral formula, which is a prerequisite of "major" electoral reforms.

\section{THE POLITICAL CONSEQUENCES OF ELECTORAL REFORMS IN CENTRAL EUROPE IN POST-TRANSITIONAL PERIOD}

Although Josep Colomer (2004) concludes that there have been a general trend towards a higher degree of proportionality in connection with electoral reform processes, Alan Renwick (2011) attributes this trend to only two types of processes, elite majority imposition and elite bargain, and only under conditions of the old democracies, while new democracies follow the trend in the direction 
away from proportionality. The examined electoral changes have confirmed the above mentioned assumption of Alan Renwick. While there is a clear tendency towards proportionality of electoral systems during the transitional phase of the politics of electoral reform in Central Europe, the cases in the post-transitional period have shown the opposite trend, with just one exception of the Slovak process of electoral reform in 1999.

On the other hand, analysis of the cases examined in the second phase of the politics of electoral reform in Central Europe has not brought any unambiguous trend in relation to the personalization of voting. This could be attributed to a certain extent to the fact that the issue of personalization of electoral systems, unlike the issue of proportionality, was not the main objective of the second phase of electoral reforms. Nevertheless, the subsequent development of electoral legislation in both the Slovak Republic (the 2006 amendment) and the Czech Republic (the 2006 amendment) may lead to the assumption that the very issue of the degree of personalization could fill the imaginary third phase of the politics of electoral reforms in Central Europe, which would strengthen the influence of ordinary voters on the final composition of the representative bodies. However, since the aforementioned amendments to the relevant electoral laws were not part of the present analysis, this is just an assumption for potential further research of electoral reforms policy (not only) in Central Europe, which would have to be verified empirically.

Table 2: Types and political consequences of electoral reforms in Central Europe in post-transitional period

\begin{tabular}{lccc}
\hline Electoral reform & Process type & Proportionality & Personalization \\
\hline Slovakia 1998 & majority imposition & medium $\searrow$ & low $\approx$ \\
\hline Slovakia 1999 & majority imposition & high $\nearrow$ & low $\approx$ \\
\hline Slovenia 2000 & settlement & medium $\approx$ & high $\approx$ \\
\hline Czech Rep. 2000 & majority imposition & low $\searrow$ & medium $\lambda$ \\
\hline Czech Rep. 2002 & elite bargain & medium $\searrow$ & medium $\lambda$ \\
\hline Hungary 2011 & majority imposition & low $\searrow$ & high $\approx$ \\
\hline Sou
\end{tabular}

Source: Charvát et al., 2015, p. 164, Table 11.1.

Notes: symbol " $\searrow$ " indicates the presence of incentives for the new electoral system to be less proportional or less personalized as compared to the previous electoral system, symbol " $\nearrow$ " indicates incentives for the new electoral system to be more proportional or more personalized, and symbol " $\approx$ " indicates no relevant change in this respect. 


\section{CONCLUSION}

Although the ability of the public to pressure for change seems to be growing in established democracies in recent decades, the Central European electoral reform processes are controlled and electoral systems decided by politicians. Politicians may be influenced by conceptions of the public interest (the reform is introduced in order to promote general values, e.g. political pluralism as it was the case during the process of democratic transition in Central European countries), as well as by partisan power interests (the system is changed to benefit those politicians who initiate the reform process). Individual reform processes hence differ in details (in addition to the nature of politicians' motivations for changes also the extent of agreement among political elites for changing the system, and so on).

Situations when politicians seeking electoral reform to advance their partisan interests, could be seen in the cases of electoral reforms in Slovakia in 1998 and in 1999, in the Czech Republic in 2000 and 2002, as well as in case of the Hungarian electoral reform process of 2011. Most of these cases were controlled by elite majority and these reform processes occurred because the elite majority had both the will to change the system and the power to impose its wishes. Only the electoral reform in the Czech Republic of 2002 and the 2000 reform in Slovenia took more or less place under the influence of intervention by external actor (it was the Constitutional Court in both cases). Furthermore, given the specific political constellations, the latter two processes were specific cases with a high degree of inclusiveness of political elite.

\section{REFERENCES}

Borisyuk, G., Rallings, C. and Thrasher, M., 2004. Selecting Indexes of Electoral Proportionality: General Properties and Relationships. Quality \& Quantity, 38(1), pp. 51-74.

Birch, S., 2003. Electoral Systems and Political Transformation in Post-Communist Europe. Basingstoke: Palgrave Macmillan.

Birch, S., Millard, F., Popescu, M. and Williams, K.. 2002. Embodying Democracy. Electoral System Design in Post-Communist Europe. Basingstoke: Palgrave Macmillan. Bowler, S. and Donovan, T., 2013. The Limits of Electoral Reform. Oxford: Oxford University Press.

Cabada, L., Charvát, J. and Stulík, O., 2015. Současná komparativní politologie: kličcové koncepty [Contemporary Comparative Politics: Key Concepts]. Praha, Plzeň: Metropolitan University Prague Press, Vydavatelství a nakladatelství Aleš Čeněk. 
Charvát, J., 2010. Proporcionalita volebních systémů: měření, problémy, vlivy [Proportionality: measures, problems, influences]. Slovenská politologická revue/Slovak Journal of Political Sciences, 10(1), pp. 2-38.

Charvát, J., 2013. Politika volebnich reforem $v \check{C} R$ po roce 1989 [The Politics of Electoral Reform in the Czech Republic]. Praha: Grada.

Charvát, J. et al. 2015. Pokušení vládnoucích: politika volebnich reforem ve střední Evropé [Temptation of the Governing: The Politics of Electoral Reform in Central Europe]. Praha: Metropolitan University Prague Press.

Chytilek, R. and Šedo, J. 2007. How the Tailor of Marrakesh Suit Has Been Altered: Advantage Ratio as a Tool in Post-Communist Electoral Reform Research. Evropská volebni studia/European Electoral Studies, 2(1), pp. 30-62.

Chytilek, R., Šedo, J., Lebeda, T. and Čaloud, D., 2009. Volební systémy [Electoral Systems]. Praha: Portál.

Colomer, J., 2004. The Strategy and History of Electoral System Choice. In: J. Colomer, ed. 2004. Handbook of Electoral System Choice. Basingstoke: Palgrave Macmillan. pp. $3-78$.

Colomer, J., 2005. It's Parties That Choose Electoral Systems (or, Duverger's Laws Upside Down. Political Studies, 53(1), pp. 1-21.

Cox, G. W., 1997. Making Votes Count. Strategic Coordination in the World's Electoral Systems. New York: Cambridge University Press.

Duverger, M.. 1954. Political Parties. London: Methuen.

Farrell, D., 2001. Electoral Systems. A Comparative Introduction. New York: Palgrave.

Ishiyama, J., 1997. Transitional Electoral Systems in Post-Communist Eastern Europe. Political Science Quarterly, 112(1), pp. 95-115.

Juberías, C. F., 1995. The Transformation of Electoral Systems in Eastern Europe and Its Political Consequences. Journal of Constitutional Law in Eastern and Central Europe, 2 (1), pp. 5-66.

Katz, R. S. 1980. A Theory of Parties and Electoral Systems. Baltimore: The Johns Hopkins University Press.

Katz, R. S. 2005. Why There Are So Many (or So Few) Electoral Reforms? In: M. Gallagher and P. Mitchell, eds. 2005. The Politics of Electoral Systems. Oxford: Oxford University Press. pp. 57-76.

Kopeček, L., 2015. Deformace demokracie? Opoziční smlouva a česká politika 19982002 [Deformation of democracy? Opposition Agreement and Czech Politics 19982002]. Brno: Barrister \& Principal.

Leyenaar, M. and Hazan, R. Y., 2011. Reconceptualising Electoral Reform. West European Politics, 34(3), pp. 437-455.

Lijphart, A., 1994. Electoral systems and Party Systems. A Study of Twenty-Seven Democracies, 1945-1990. Oxford: Oxford University Press.

Lundell, K., 2010. The Origin of Electoral Systems in the Post-war Era: A worldwide approach. London, New York: Routledge. 
Monroe, B. L., 1994. Disproportionality and Malapportionment: Measuring Electoral Inequity. Electoral Studies, 13 (2), pp. 132-149.

Nohlen, D., 1984. Changes and Choices in Electoral Systems. In: A. Lijphart and B. Grofman, eds. 1984. Choosing an Electoral System. Issues and Alternatives. New York: Praeger. pp. 217-224.

Pilet, J.-B. and Bol, D., 2011. Party Preferences and Electoral Reform: How Time in Government Affects the Likelihood of Supporting Electoral Change. West European Politics, 34(3), pp. 568-586.

Rae, D. W., 1967/1971. The Political Consequences of Electoral Laws. New Haven: Yale University Press.

Renwick, A., 2010. The Politics of Electoral Reform. Changing the Rules of Democracy. Cambridge: Cambridge University Press.

Renwick, A., 2011. Electoral Reform in Europe since 1945. West European Politics, 34(3), pp. 456-477.

Roberts, A., 2003. Demythologising the Czech Opposition Agreement. Europe-Asia Studies, 55 (8), pp. 1273-1303.

Rose, R. and Munro, N., 2003. Elections and Parties in New Democracies. Washington, D. C.: CQ Press.

Sartori, G., 1968. Political Development and Political Engineering. In: J. D. Montgomery and A. O. Hirschman, eds. 1968. Public Policy, Vol. XVII. Cambridge: Harvard University Press. pp. 261-298.

Šedo, J., 2007. Volební systémy postkomunistických zemí [Electoral Systems in PostCommunist Countries]. Brno: CDK.

Taagepera, R. and Grofman, B., 2003. Mapping the Indices of Seats-Votes Disproportionality and Inter-Election Volatility. Party Politics, 9(6), pp. 659-677.

Taagepera, R. and Shugart, M. S., 1989. Seats and Votes. The Effects and Determinants of Electoral Systems. New Haven: Yale University Press.

Tsebelis, G., 1990. Nested Games. Rational Choice in Comparative Politics. Berkeley, Los Angeles: University of California Press. 